\title{
BRICS, SCO AND NEW MECHANISMS OF GLOBAL GOVERNANCE
}

Georgy Toloraya, Executive Director, National Committee for BRICS Studies.

\section{Summary}

The paper deals in detail with the purposes of creation and functioning of BRICS. The activities of BRICS and SCO are compared; the prospects of building new political, economic and financial architecture are examined. Dialogue of civilizations is expected to develop further under the auspices of international multilateral structures.

Key words: BRICS, SCO, global governance, union of civilizations, financial system, summit.

\section{K. XAC \\ ПОДХОД ТУРЦИИ К ШОС: ВОЗМОННЫЙ ВКЛАД В РЕГИОНАЛЬНУЮ БЕЗОПАСНОСТЬ И ЭКОНОМИЧЕСКОЕ ПРОЦВЕТАНИЕ}

Керим Хас, московский представитель Международной организации стратегических исследований (Туриия).

\section{Аннотация}

В статье обсуждаются выгоды от сотрудничества Туриии со странами ШОС. Экономические показатели Турции свидетельствуют о сдвиге объемов торговли от Европы к Азии, страна заинтересована в создании свободных экономических зон в регионе и поддерживает прочие инициативы Китая. Оставаясь членом НАТО, Туриия стремится вместе с тем к углубленному сотрудничеству в сфере безопасности с соседними странами. Особо важны в этом смысле отношения с Афганистаном.

Ключевые слова: Турция, внешняя политика, ШОС, экономическое развитие, Татарстан, зоны свободной торговли, региональная безопасность, Афганистан, НАТО.

Турция уже демонстрировала свое внешнеполитическое отношение к Шанхайской организации. Речь шла о присоединении Турции к ШОС, как заявлялось на встрече между президентами Турции и России. Обсуждалось развитие взаимоотношений с этой Организацией. За этим новым подходом Анкары просматривается изменение всей схемы ее внешней политики. В 2000-х гг. Анкара постоянно говорила о заинтересованности в развитии региональных связей. Для доказательства этого в 2005 г. Турция приобрела статус наблюдателя в ШОС. В 2008 г. она воспринималась как стратегический партнер. В октябре 2009 г. Турция со странами - основателями ШОС: Азербайджаном, Кыргызстаном, Казахстаном, - говорила о создании Совета, который бы координировал работу международных организаций в решении региональных экономических и культурных вопросов. Более того, развивая новый дипломатический подход в ЮгоВосточной Азии, Турция выстраивала свои отношения с АСЕАН. В 2010 г. Турция углубляет свои отношения с ШОС и предпринимает следующие, скоординированные в рамках всей внешней политики, шаги. На встрече лидеров ШОС Турция получила 
статус партнера по диалогу, который был подкреплен церемонией подписания официального меморандума. Необходимо подчеркнуть, что в этот момент произошел сдвиг в геополитике с Североамериканского на Юго-Восточный регион, на укрепление связей с Китаем. Турция стала больше развивать свою азиатскую стратегию и принимать более активное участие в работе региональных организаций. В соответствии с этой новой региональной стратегией Турция желает перейти от статуса партнера по диалогу и наблюдателя к полноправному членству в названных организациях.

С другой стороны, внутренняя политика Турции также ориентируется на мультивекторность и изменение основных направлений работы правящей партии. В членстве в ШОС мы видим возможность роста ВВП Турции: 21 \% всего импорта страны в прошлом году приходилось на страны ШОС, включая страны - наблюдатели и партнеры по диалогу.

В 2014 г. общий импорт Турции из стран ШОС, включая членов группы, превысил 7 млрд долл. Этот показатель растет, хотя некоторые из этих стран, включая Россию и Иран, находятся под западными санкциями. Таким образом, существует огромный потенциал взаимодействия между Турцией и ШОС. В то же время с 2003 по 2015 гг. доля ЕС в общем импорте Турции сократилась с 51 до 36 \%, та же тенденция наблюдается в экспорте Турции, около 58 \% которого приходится на страны восточного региона. Экспорт Турции в страны ШОС вырос примерно на 6,5 \%. Но говорить о значительном росте в торгово-экономических отношениях со странами ШОС рано. Необходимо усиление, ускорение торгово-экономических связей. Анкара заинтересована в создании зоны свободной торговли со странами ШОС. Уникальное географическое положение Турции между Европой и Азией предоставляет очень хорошие возможности для китайского проекта «Шелковый путь», где сплетаются цивилизационный и культурный компоненты.

Анкара стремится к партнерским отношениям с отдельными странами и ШОС в целом. Турция не принимает участия в санкционной политике против России, и это усиливает шансы создания отношений доверия между Турцией и странами ШОС. Стремительное улучшение в последнее десятилетие экономических связей между Турцией и Республикой Татарстан как субъекта Федерации России также дает дополнительную уверенность в дальнейшем укреплении этих отношений. После распада СССР во взаимоотношениях между Россией и Турцией были определенные сложности, но развитие связей между Турцией и Татарстаном показывает, что существует огромный потенциал инвестиционной, экономической политики. Сейчас в региональную экономику уже вложено несколько миллиардов долларов прямых инвестиций. Аналогичный подход существует во взаимоотношениях Турции и Синьцзян-Уйгурского автономного района Китая. Мы можем применять механизмы свободной торговли во взаимоотношениях с Китаем. Такие интеграционные проекты отвечают интересам всех стран Организации, а не только Турции.

Терроризм, сепаратизм представляют опасность и для Турции. События, происходящие в Ираке, несут прямую угрозу Турции. Наконец, подъем сепаратизма во многих странах региона также способствует тому, чтобы Анкара стремилась к установлению более тесных контактов на двухстороннем и многостороннем уровнях с региональными организациями. Мы должны все вместе работать, чтобы успешно преодолеть, победить эти угрозы.

На стороне ИГИЛ сейчас воюет большое количество людей из центральноазиатских республик. Это также очень большая проблема для стран региона. С другой стороны, процветание Афганистана, развитие его экономики и социально-культурной сферы необходимы не только для народа Афганистана, но и для всего региона. Турция вовлечена в события в Афганистане. Хотя Турция, совместно с другими европейскими странами, стремилась к выводу своих войск из Афганистана, но при исполнении этой миссии Турция стала единственной страной, которая увеличила свой контингент в стране. 
Турция вносит свой вклад в подготовку вооруженных сил в Афганистане и проведение военных реформ. Анкара оказывает официальную помощь Афганистану через Агентство сотрудничества и развития. Использование элементов мягкой силы в Афганистане находит выражение в сфере образования, медицины, транспорта, развитии инфраструктуры. Гуманитарный характер присутствия Турции в этом регионе способствует усилению связей с Афганистаном.

По статистическим данным, Турция осуществила в этом регионе в течение нескольких лет около 800 проектов, из них 200 - в сфере образования, еще около 200 - в сфере медицины. Около 100 тыс. афганских студентов обучались в различных учебных заведениях Турции. Сфера медицинских услуг Турции активно растет. Развитие гуманитарных связей и экономической интеграции со своими соседями позволит снизить радикальные тенденции в афганском обществе и вырастить новое по качеству поколение. Огромный турецкий опыт в решении этих вопросов в Афганистане предоставляет возможность нового аспекта вклада Турции в деятельность ШОС.

Турция готова пересмотреть свою военную политику в отношении ШОС. Турция ведет переговоры с Китаем по ракетам дальнего радиуса действия, по передаче технологий. Если все обсуждаемое реализуется, то можно будет говорить о новой эре турецко-китайского военного сотрудничества. Турция уже долгое время ведет работу с Россией по различным военно-политическим аспектам. Анкара впервые из членов НАТО проводит такую серьезную работу, и это может иметь прямое существенное влияние на взаимоотношения Турции с Западом. Но не следует считать, что экономическая ориентация на ШОС означает смену внешнеполитического вектора. Турция на сегодня пока не готова отказаться от своей западной ориентации и перейти к полноправному членству в ШОС.

Итак, Турция может внести вклад в построение архитектуры безопасности, экономическое процветание региона ШОС через развитие тесного сотрудничества с институтами Запада и экономическую диверсификацию. В этом контексте единство интересов Турции и стран ШОС может иметь прямое позитивное влияние на сотрудничество и взаимоотношения между ШОС и Западом.

\title{
TURKEY'S SCO PERSPECTIVE: POSSIBLE CONTRIBUTIONS TO THE REGIONAL SECURITY ARCHITECTURE AND ECONOMIC PROSPERITY
}

\author{
Kerim Has, Moscow Representative, International Strategic Studies Organization.
}

\author{
Summary \\ The paper discusses the benefits of Turkey's cooperation with SCO countries. Turkey's economic \\ indices reveal the shift of trade volumes from Europe to Asia, the country is interested in free trade zones \\ in the region and support most initiatives brought forward by China. Being the member of NATO Tur- \\ key seeks nevertheless fundamental security co-operation with adjacent states. Especially important for \\ Turkey are relations with Afghanistan
}

Key words: Turkey, foreign policy, SCO, economic development, Tatarstan, free trade zones, regional security, Afghanistan, NATO. 